\title{
The Impact of Forestry Sector Investments on Household Income and Carbon Emission: Case Study of Berbak National Park, Jambi Province, Indonesia
}

\author{
Heriberta $^{{ }^{*}}$, Zulfanetti ${ }^{1}$, Muhammad Ridwansyah ${ }^{1}$ and Havidz Aima ${ }^{2}$ \\ ${ }^{1}$ Faculty of Economics and Business, University of Jambi, Kampus Pinang Masak Jl. Raya Jambi-Ma Bulian KM. 15, Mendalo Darat, Jambi, Indonesia
} ${ }^{2}$ Profesor of Magister Management Program, University of Mercu Buana, Indonesia

\author{
DOI: $10.36348 /$ SJEF.2019.v03i09.007 \\ | Received: 07.09.2019| Accepted: 14.09.2019| Published: 29.09.2019 \\ *Corresponding author: Heriberta
}

\section{Abstract}

This study focused on Jambi Province (Sumatera) which experienced a massive forest fire in 2015. It had destroyed 19,528 ha of land in including Berbak National Park. These fires directly lead to economic losses of the households near National Park and neighboring provinces. This study used a Social Accounting Matrix framework (simple version of a general equilibrium model) to simulate two scenarios if the government invest on reforestation and rehabilitation of forest and how it affected the household incomes for agriculture and non-agriculture groups in Jambi Province. The investment is estimated from the budget allocated for activities in the Berbak Region. From the simulation, the result showed rural and urban areas are positively affected under both scenarios due to the forestry investment. The positive impacts on the rural and urban households are relatively small in the first simulation, but more positively affected in the second simulation, however, it seems to intensify the income gap for workers and employers. The simulation results also indicated the absorption capacity of $\mathrm{CO}_{2}$ increases between 111 percent and 284 percent due to the investment in Berbak National Park.

Keywords: Social Accounting Matrix; Forestry Investment; Forest Fire.

Copyright @ 2019: This is an open-access article distributed under the terms of the Creative Commons Attribution license which permits unrestricted use, distribution, and reproduction in any medium for non-commercial use (NonCommercial, or CC-BY-NC) provided the original author and source are credited.

\section{INTRODUCTION}

Forest is one of the most important resources for life, providing raw materials used for industries [1], source of medicinal plants, ecotourism, genetic bank [2], and supplier for goods and services both directly and indirectly to the community [3]. Forests not only for the economy as a source of foreign exchange, but also a essential role in sustaining people's daily lives, especially on social and cultural values for the local community [4].

Indonesia is the world's largest archipelagic nation which 63 percent of its total land area (120.6 million hectares of land) designated as the forest area. The forests are home to thousands of plants and animal species, and 50-60 million Indonesians depend directly on the forests for their livelihoods [5]. Indonesia employs a different definition of "forest" than those sometimes used elsewhere in the world. Under Indonesian law, a forest is defined as " a land area of more than 6.25 hectares with trees higher than 5 meters at maturity and a canopy cover of more than 30 percent" [6]. Being the third largest area of tropical forest in the world, Indonesia's forests play a significant role in climate change mitigation at the national and global level.

Besides deforestation, among another significant issue in Indonesia is a "forest fire". These forest fires have become a predictable and intractable annual problem for the country [7]. Five provinces; Riau, Jambi, South Sumatra, West Kalimantan and South Kalimantan are among the hot spots of the forest fire because huge chunks of its land lying upon peat, which is flammable like coal especially during El Niño climate cycle. The fires affected a large portion of the Indonesian population causing economic hardship and disruption to commerce, short and long term health problems [8] including rising $\mathrm{CO}_{2}$ emission. With the above-mentioned problems, the Indonesian government must develop various investments or interventions planning to protect the forest.

Sumatra formerly had more than 10 million ha of peat swamp forests; much of it is found in the Berbak National Park which is 185,000 ha [9-11]. During the El 
Niño drought in 1997-98, fires swept through Southeast Asia's lowland forests, especially the peat swamp forests and an estimated 1-2.5 billion tons of carbon were released to the atmosphere, amounting to $15-40 \%$ of the global annual emission [12, 13]. These fires directly lead to economic losses in excess of US\$ 9 billion [14]. Berbak National Park was also affected, and more than 17,000 ha were burnt in 1997-1998 alone [15]. Another massive forest fire in 2015 destroyed 19,528 ha of land and forests in Jambi. According to the Jambi Forestry Agency, 566 ha of land and forests across the province were burned down in 2017, including the huge area of Berbak National Park. The forest fire covering 227 ha in the mangrove forest area and conservation forest (swamp water), including 181 ha on community land or outside the forest area of Berbak National Park. The forest fire directly affected the economic condition of the households near the forest as some of the villagers being a porter and accompanying researchers or tourists visiting the Berbak National Park. Some of them also provide homestay services as part of ecotourism activity around Berbak National Park. The economic loss due to forest fires is IDR 23.905 million/ha [16].

Therefore, this study used a Social Accounting Matrix framework (simple version of a general equilibrium model) to simulate the scenario if the government invest on reforestation and rehabilitation of forest and how it would impact the household incomes for agriculture and non-agriculture groups in Jambi Province. The government investment in the forestry sector is assumed not only benefits to the villagers around the Berbak National Park but also to Jambi province as a whole. The carbon emission is expected to reduce due to the investment. The existing problems are of particular concern to be studied.

\section{METHODOLOGY \\ Study area}

The Berbak Forest has an area of 110,000 ha of peat swamp forest ecosystem and 60,000 ha of freshwater swamp forest [17]. It is a natural conservation area and considered as the largest conservation of swamp forest in Southeast Asia that has not been exploited by the human. Within Berbak Forest, 142,750 ha are assigned for National Park as a conservation area; the remaining area is for agricultural land. Berbak National Park is protected nationally as well as internationally which has been designated as an International Wetland in the RAMSAR convention since 1992. Berbak National Park has 4 zones: 1) core zone, 2) jungle zone, 3) rehabilitation zone and 4) utilization zone.

The forest also functions as $\mathrm{CO}_{2}$ absorbers. On average, the biomass content of Berbak National Park is 370 tons/ha above ground and 80 tons/ha below ground and when linked to REDD projects, the carbon content is 58.57 million tons covering an area of 162,700 ha [18]. However, Berbak National Park also affected by forest fires on a fairly large scale and seizes the attention of the government. In 2003, in amount of 278 hotspots were detected within 1,025 hectares of burned forest area and in 2006 with a total of 548 hotspots scattered within a total area of 408 ha. The forest fires also affected community land or outside forest areas where the National Park is buffered by 11 villages within two sub-districts; Berbak (19.446 ha) and Sadu $(182.120 \mathrm{ha})$ and inhabited by 8,831 households. Among the villagers are agricultural households.

Table-1: Villages around Berbak National Park

\begin{tabular}{|l|l|c|}
\hline Sub-districts & Villages & Number of Families \\
\hline Berbak & 1. Sungai Rambut & 370 \\
& 2. Rantau Rasau & 587 \\
& 3. Simpang Datuk & 478 \\
& 4. Sungai Jambat & 412 \\
& 5. Sungai Sayang & 512 \\
& 6. Remau Baku Tuo & 465 \\
& 7. Telago Tuo & 395 \\
\hline Sadu & 1. Air Hitam Laut & 398 \\
& 2. Sungai Cemara & 439 \\
& 3. Labuan Pering & 397 \\
& 4. Sungai Benuh & 387 \\
\hline
\end{tabular}




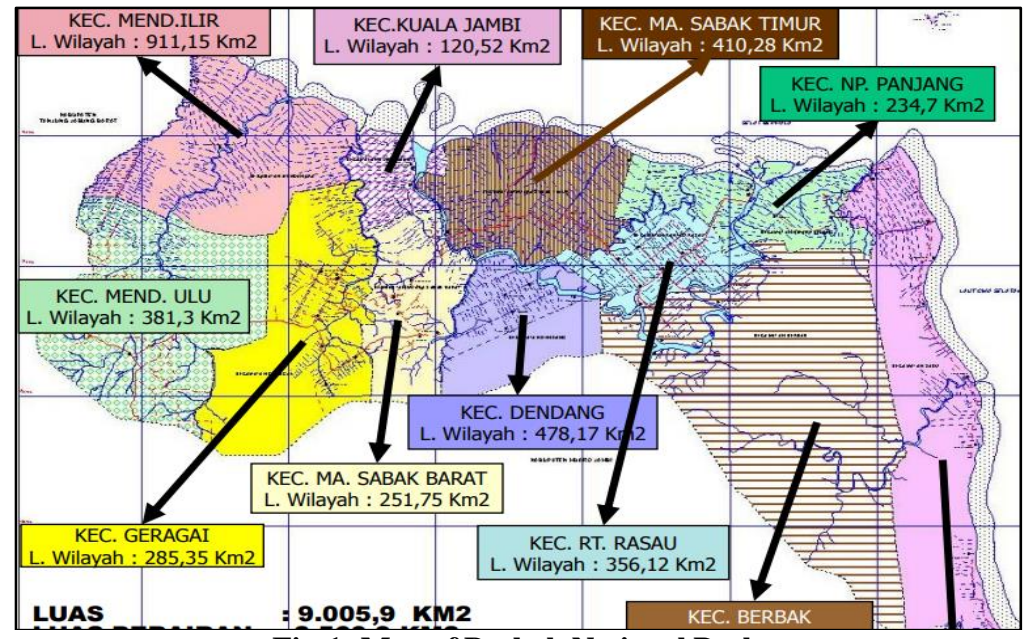

Fig-1: Map of Berbak National Park

\section{Data analize}

Impact analysis of investment is used to determine either the effect of a particular policy change in regional economic activity or the contribution of growth or decline in a given industry [19]. There are three primary approaches used to estimate economywide or general equilibrium socio-economic impacts of changes in an economy, Input-output (I-O) models, Social Accounting Matrix (SAM) models, and the computable general equilibrium (CGE) models [20]. SAM is a matrix representation of transactions in a socioeconomic system. It is comprehensive, flexible and disaggregated framework elaborates and articulates the generation of income by activities of production, distribution and redistribution of income between social and institutional groups [21] and allow for examining changes in income distribution under various scenarios [19]. SAM can be used for some simple policy simulations and supporting the policy decision process [22]. SAM also an important analyzing tool because: (1) its multiplier coefficients can properly describe economic policy impacts on a household's income, hence illustrating the economic policy impact on income distribution; and (2) the application is relatively simple, thus it can be easily applied to various countries [23].

Studies using SAM in the forestry sector are still few in Indonesia. Yusuf and Resosudarmo [24] and Nurdianto and Resosudarmo [25] analyzed the impact of the carbon tax on the economy. Nurdianto and Resosudarmo [25] focus on ASEAN countries whereas Yusuf and Resosudarmo [24] particularly study on Indonesia. In general and at least in the short-run period, a carbon tax is an effective way of reducing carbon emissions in ASEAN countries. Ambiyah and Jupesta [26] assessed the impact of fiscal policies in green forestry and renewable energy on household income and job creation using IRSAM (Inter-regional social accounting matrix). The simulation scenario on fiscal policy on green forestry, green oil palm and green renewable energy sectors (a 10\% increase in local government spending on those selected sectors in each region) has positive impacts on labor, household income, and output. The study found that investment or fiscal policies implemented in the green sectors in Indonesia will have positive impacts on the economy. The rest of the literature dominated on energy [29, 28], and government fiscal policy [23].

Given the advantage of SAM to simulate scenarios and observe policy changes, this study employed the model to estimate the impact of forestry sector investment on household income in Jambi. Indonesian Statistics Office (BPS) publishes SAM every five years since 1975. An official Indonesian SAM has 23 sectoral in terms of household classification and distinguishes only 10 household groups according to their occupational status. This classification, however, is sufficient to compare and contrast the policy impact among socioeconomic classes [21]. Further, Yusuf [29] makes substantial effort to extend the household classification in the 2003 Indonesia SAM to represent urban and rural household percentile income. His work contributes to the possibility to assess the poverty and distributional income effect of the policy.

This study used 2012 Input-Output (I-O) table which then was disaggregated into SAM to analyze the role of the forestry sector in the Jambi Province. The 2012 Jambi Province SAM was formed from Jambi Province I-O table 2007, upgraded to I-O table 2012 with a $53 \times 53$ matrix, then disaggregated become the 2012 SAM with a $72 \times 72$ matrix.

$$
(I M)=n \sum_{j=1}^{n} \alpha_{i j}^{a a} / \sum_{i=1}^{n} \sum_{j=1}^{n} \alpha_{i j}^{a a}
$$

$\alpha_{i j}^{a a}$ : The row element $\mathrm{i}$ column $\mathrm{j}$ of the block of production activity (aa) on the output multiplier $(I-A)^{-1}$

$\mathrm{N}$ : Number of production sectors $(\mathrm{n}=53)$ 


\section{Scenario}

The typical ultimate goal of an analysis using SAM is to understand what impacts a policy creates on household incomes. Two simple scenario simulations are conducted to observe the impact of government investment in the forestry sector through reforestation and rehabilitation. The investment is estimated from the planning activities in the Berbak Region of Jambi Province. Based on the Forestry Agency of Jambi Province, about IDR 300-400 million is allocated for the forest activities of the province in 2015 . The policy impact then was analyzed in 2018.

Scenario 1: Investment in the timber and nontimber industry, and other forest products of IDR 1.032 billion

Scenario 2: Investment in the timber and nontimber industry, and other forest products of IDR 2.580 billion

Table-2: Planning for Forest Investment Activities in the Berbak Region of Jambi Province

\begin{tabular}{|c|c|c|c|c|c|c|}
\hline & Item & $\begin{array}{l}\text { Forest Area } \\
\text { (Ha) }\end{array}$ & $\begin{array}{l}\text { Forest to } \\
\text { be } \\
\text { managed } \\
\text { (Ha) } \\
\end{array}$ & $\begin{array}{l}\text { Remaining } \\
\text { Forest to be } \\
\text { managed (ha) }\end{array}$ & IDR(Million) & IDR(Million) \\
\hline 1. & Forest Area & $2,100,000$ & & & & \\
\hline 2. & Forest area UU $30 \%$ x 5.2 million ha & $1,560,000$ & 540,000 & & & \\
\hline 3. & HTI that has been managed & 663,721 & & & & \\
\hline 4. & HTI established & 780,000 & & & & \\
\hline 5. & $\begin{array}{l}\text { Land Opportunities that must be } \\
\text { managed by HTI }\end{array}$ & & 116,279 & 116,279 & 12,000 & $1,395,350$ \\
\hline 6. & $\begin{array}{l}\text { Community-Based Forest Management: } \\
\text {-Hutan Kemasyarakatan (HKm) } \\
\text { - Hutan Desa (HD) } \\
\text { - Hutan Tanaman Rakyat (HTR) }\end{array}$ & $\begin{array}{l}21,000 \\
25,000 \\
54,000\end{array}$ & 100,000 & & & \\
\hline & Total & & 313,721 & 313,721 & 12,000 & $3,764,650$ \\
\hline \multicolumn{4}{|c|}{ Total rehabilitation cost } & 430,000 & & $5,160,000$ \\
\hline \multicolumn{4}{|c|}{ Managed in timber industry forests } & 116,418 & & $1,395,350$ \\
\hline \multicolumn{4}{|c|}{ Managed in non-timber industrial forests } & 212,639 & & $2,550,000$ \\
\hline \multicolumn{4}{|c|}{ Managed in other forest products } & 100,943 & & $1,209,650$ \\
\hline
\end{tabular}

\section{Carbon emission}

The investment in the forestry sector is expected to reduce carbon emission. The emission coefficient obtained is made in the form of a matrix called the emission coefficient matrix (Dj). The matrix is multiplied by the balance sheet matrix multiplier or (I A) -1 and the result is an emission multiplier matrix (T). Mathematically formulated as follows: $\mathrm{T}=\mathrm{D}_{\mathbf{j}}(\mathrm{I}-\mathrm{A})^{-1}$

\section{RESULTS AND DISCUSSION Household income}

SAM is used to compute multipliers effect under two scenarios for eight household categories related to agriculture and non-agriculture groups. In Table 3, it shows the number of agricultural and non-agricultural households in Jambi Province amounted to 828,993 households. Generally, the impact of these two scenarios is quite the same. In the first simulation when the government invests IDR 1.032 billion, the household income for both groups; agriculture and nonagriculture household increases. The highest increases showed by Rural Agriculture Entrepreneur about 1.77\% whereas for non-agriculture households indicated by
Urban Non-Agriculture Entrepreneur about $1.53 \%$. This is because the investment in the forestry sector funded by the government is given to the entrepreneurs both in rural and urban areas. The fund is not directly transferred to the surrounding community, which most of them only work as labors.

In the second simulation, the bigger investment creates a bigger impact on the household income for both groups; agriculture and non-agriculture. When the government invests IDR 2.580 billion, it positively affected all households groups with the highest impact goes to the same group as in scenario one. The same reason holds true for the second simulation, where entrepreneurs received the highest impact due to the investment. This increase may intensify the income gap for workers and employers.

The quantitative information obtained from the analysis indicates that forestry investment positively improves the economy by increasing the income of agriculture and non-agriculture households, both for rural and urban. 
Table-3: Income received by agricultural and non-agricultural households as the impact of investment of Berbak

\begin{tabular}{|c|c|c|c|c|c|c|}
\hline \multicolumn{7}{|c|}{ National Park } \\
\hline $\begin{array}{l}\text { Household } \\
\text { Categories }\end{array}$ & $\begin{array}{l}\text { Total } \\
\text { Families } \\
\text { (People) }\end{array}$ & $\begin{array}{l}\text { Before } \\
\text { Investment } \\
\text { (monthly } \\
\text { income) }\end{array}$ & $\begin{array}{l}\text { After } \\
\text { Investment } \\
\text { IDR 1.032 } \\
\text { Billion }\end{array}$ & $\begin{array}{l}\text { \% of increase } \\
\text { after } \\
\text { investment }\end{array}$ & $\begin{array}{l}\text { After } \\
\text { Investment } \\
\text { IDR 2.580 } \\
\text { Billion }\end{array}$ & $\begin{array}{l}\% \text { of increase } \\
\text { after } \\
\text { investment }\end{array}$ \\
\hline $\begin{array}{l}\text { Rural } \\
\text { Agriculture } \\
\text { Workers }\end{array}$ & 40,934 & $4,176,276$ & $4,225,834$ & 1.19 & $4,305,008$ & 3.08 \\
\hline $\begin{array}{l}\text { Urban } \\
\text { Agriculture } \\
\text { Workers }\end{array}$ & 39,712 & $4,051,579$ & $4,089,997$ & 0.95 & $4,151,321$ & 2.46 \\
\hline $\begin{array}{l}\text { Rural } \\
\text { Agriculture } \\
\text { Entrepreneur }\end{array}$ & 250,536 & $7,968,108$ & $8,109,081$ & 1.77 & $8,332,953$ & 4.58 \\
\hline $\begin{array}{l}\text { Urban } \\
\text { Agriculture } \\
\text { Entrepreneur }\end{array}$ & 289,864 & $9,218,909$ & $9,352,000$ & 1.44 & $9,564,839$ & 3.75 \\
\hline $\begin{array}{l}\text { Rural Non- } \\
\text { Agriculture } \\
\text { Workers }\end{array}$ & 61,561 & $3,703,226$ & $3,753,340$ & 1.35 & $3,833,501$ & 3.52 \\
\hline $\begin{array}{l}\text { Urban Non- } \\
\text { Agriculture } \\
\text { Workers }\end{array}$ & 64,981 & $3,908,938$ & $3,965,567$ & 1.45 & $4,056,124$ & 3.77 \\
\hline $\begin{array}{l}\text { Rural Non } \\
\text { Agriculture } \\
\text { Entrepreneur }\end{array}$ & 30,118 & $13,658,847$ & $13,861,763$ & 1.49 & $14,184,647$ & 3.85 \\
\hline $\begin{array}{l}\text { Urban Non } \\
\text { Agriculture } \\
\text { Entrepreneur }\end{array}$ & 51,287 & $23,259,063$ & $23,861,763$ & 1.53 & $24,183,592$ & 3.97 \\
\hline
\end{tabular}

\section{CARBON EMISSION}

Before the investment, the agriculture and nonagriculture household produce $\mathrm{CO}_{2}$ amounted to 29,834 MT (average). After the investment of IDR 1.03 trillion, the emission is increased due to economic activity with the average emission of 30,285 MT. It holds true for the investment of IDR 2.58 trillion, the $\mathrm{CO}_{2}$ emission is greater, about 31,002 MT. The agriculture entrepreneurs from rural and urban are identified as the highest contributors.

However, based on the calculations through SAM, after investing IDR 1.032 billion, the Berbak
National Park is able to absorb 24,620,955.95 MT of $\mathrm{CO}_{2}$ (or increase the absorption of $\mathrm{CO} 2$ emissions by 284 percent), where the normal condition before the investment is only $6,413,065,447$ MT. Whereas, if the investment is IDR 2.580 billion, the Berbak National Park is able to absorb $\mathrm{CO}_{2}$ emissions of 52,030,088.18 MT or increase $\mathrm{CO}_{2}$ absorption by 111 percent. It means, if government invest in reforestation and forest rehabilitation, the volumes of Berbak National Park to absorb the emission is significantly increased between 111 percent and 284 percent, and balance-off the emission from the surrounding area.

Table-4: Total $\mathrm{CO}_{2}$ emission by a household after the investment

\begin{tabular}{|r|c|c|c|}
\hline Household Categories & $\begin{array}{r}\text { Total CO } \\
\text { Emission } \\
(\mathbf{M T})\end{array}$ & $\begin{array}{r}\text { Total } \mathbf{C O}_{\mathbf{2}} \text { emission } \\
\text { after investment IDR } \\
\mathbf{1 . 0 3 2} \text { Billion (MT) }\end{array}$ & $\begin{array}{r}\text { Total CO } \\
\text { after } \text { after emission } \\
\text { 2.580 Billion (MT) }\end{array}$ \\
\hline Rural Agriculture Workers & $11,276.64$ & $11,410.46$ & $11,624.24$ \\
\hline Urban Agriculture Workers & $8,121.98$ & $8,198.99$ & $8,321.93$ \\
\hline Rural Agriculture Entrepreneur & $51,161.65$ & $52,066.81$ & $53,504.25$ \\
\hline Urban Agriculture Entrepreneur & $53,694.09$ & $54,469.26$ & $55,708.90$ \\
\hline Rural Non-Agriculture Workers & $7,217.43$ & $7,315.10$ & $7,471.32$ \\
\hline Urban Non-Agriculture Workers & $7,847.10$ & $7,960.78$ & $8,142.57$ \\
\hline Rural Non Agriculture Entrepreneur & $48,664.32$ & $49,387.28$ & $50,537.67$ \\
\hline Urban Non Agriculture Entrepreneur & $50,690.92$ & $51,467.62$ & $52,705.84$ \\
\hline Average & 29,834 & 30,285 & 31,002 \\
\hline
\end{tabular}




\section{CONCLUSIONS}

- Berbak National Park which is the Ramsar Site, surrounded by 11 villages with a total forest area of $162,700 \mathrm{ha}$. Of the total forest area, 110,000 ha is peat swamp forest ecosystem and 60,000 ha is freshwater swamp forest where peatland is prone to forest fires.

- In 2015, a forest fire had destroyed a massive area of Jambi including Berbak National Park. It not only damaged the forest but also affected the income of villagers around the forest. The government investment through reforestation and rehabilitation is assumed to improve the social condition of the related households.

- This study employed SAM and conducted simple scenarios with two different amount of forest investment (reforestation and rehabilitation) to further estimate the changes in household income. From the simulation, the results showed rural and urban areas are positively affected under both scenarios due to the forestry investment. The positive impacts on the rural and urban households are relatively small in the first simulation, but more positively affected in the second simulation due to an income increase for both groups, however, it seems to intensify the income gap for both workers and employers.

- The simulation results indicate the absorption capacity of $\mathrm{CO}_{2}$ is increasing between 111 percent and 284 percent due to the investment by the government.

\section{ACKNOWLEDGEMENTS}

This study is funded by DIPA PNBP, Faculty of Economics and Business Jambi University, under Senior Lecturer Program Budget Year 2018. Number: SP DIPA-042.01.2.400950 / 2018 December 5, 2017, in accordance with the Research Contract Agreement Number: 1698 / UN21.17 / LT2018 April 23, 2018.

\section{REFERENCES}

1. Abdullah., Ambiyah., Jupesta, J. (2015). Assessing the impact of fiscal policies in green forestry and renewable energy sectors on poverty reduction and job creation in Indonesia. Third Annual Conference Fiscal Policies and the Green Economy Transition: Generating Knowledge - Creating Impact; 2015 January 29-30; Ca' Foscari University of Venice, Venice, Italy. 2015.

2. Applegate, G., Smith, R., Fox, J. J., Mitchell, A., Packham, D., Tapper, N., \& Baines, G. (2002). Forest fires in Indonesia: impacts and solutions. Which way forward, 293-308.

3. CIFOR. (2019). Measuring Carbon: Jambi and Berbak, National Park, Sumatra. 2015 [cited 2019 February 16]. Available from : https://www.cifor.org/redd-benefitsharing/measuring-carbon-jambi-berbak-nationalpark-sumatra-photo-james-maidencifor/
4. Darusman, D.(2002. Pembenahan Kehutanan Indonesia. Lab. Politik Ekonomi dan Sosial Kehutanan, Fakultas Kehutanan, Institut Pertanian Bogor.

5. Fathurrahman, F., Kat, B., \& Soytaș, U. (2017). Simulating Indonesian fuel subsidy reform: a social accounting matrix analysis. Annals of Operations Research, 255(1-2), 591-615.

6. Giesen, W. (1993). The State of Natural Wetlands in Sumatra: Implications for conservation, and the general trend in Indonesia. Paper presented at the Workshop on Tropical Environmental Management: Biodiversity for Sustainable Development in SE Asia. Wallace Research University, Dumoga Bone NP, North Sulawesi, 818.

7. Hartono, D., \& Resosudarmo, B. P. (2008). The economy-wide impact of controlling energy consumption in Indonesia: An analysis using a Social Accounting Matrix framework. Energy Policy, 36(4), 1404-1419.

8. Hughes, D. W. (2000). Economic implications of forest products sector industry development in northwest Louisiana.

9. Krithika, V. (2017). Indonesia Forest Fires Intractable Problem, Despite Efforts. [Internet] 2017 [cited 2019 March 15]. Available from: https://www.voanews.com/a/indonesia-forest-firesintractable-problem-despite-efforts/3982129.html

10. Ministry of Environment and Forestry. (2018). The State of Indonesia's Forests 2018. Ministry of Environment and Forestry, Republic of Indonesia.

11. Nurdianto, D. A., \& Resosudarmo, B. P. (2016). The economy-wide impact of a uniform carbon tax in ASEAN. Journal of Southeast Asian Economies, 1-22.

12. Parish, F., \& Looi, C. C. (1999). Wetlands, biodiversity and climate change. In Options and needs for enhanced linkage between the Ramsar convention on wetlands, Convention on Biological Diversity andUN Framework Convention on Climate Change.

13. Resosudarmo, B. P., Nurdianto, D. A., \& Hartono, D. (2009). The Indonesian inter-regional social accounting matrix for fiscal decentralization analysis. Journal of Indonesian Economy and Business, 24(2), 145-162.

14. Rieley, J.O., Page, S.E. (2004). Peatland of Southeast Asia - Is there a future? Peatlands International 1/2004: 49-54.

15. Santos, S. (2018). Using a Social Accounting Matrix for analysing institutions' income: a case from Portugal. Sustainability Assessment and Reporting, 1.

16. Siegert, F., Ruecker, G., Hinrichs, A., \& Hoffmann, A. A. (2001). Increased damage from fires in logged forests during droughts caused by $\mathrm{El}$ Nino. Nature, 414(6862), 437.

17. Silvius, M. J., Simons, H. W., \& Verheugt, W. J. M. (1984). Soils, vegetation, fauna and nature 
conservation of the Berbak game reserve, Sumatra, Indonesia (No. 1984-3). RIN.

18. Silvius, M. J., \& Giesen, W. (1996). Towards integrated management of swamp forests. A case study from Sumatra. IUCN, GLAND(SWITZERLAND). 1996.

19. White, W. A., \& Patriquin, M. N. (2003). A regional economic impact modelling framework. Project paper 0398-C1 submitted to XII World Forestry Congress.

20. World Resource Institute. (2019). Forests and Landscapes in Indonesia. 2018 [cited 2019 March 20]. Available from: https://www.wri.org/ourwork/project/forests-and-landscapes-indonesia

21. Wösten, J. H. M., Van Den Berg, J., Van Eijk, P., Gevers, G. J. M., Giesen, W. B. J. T., Hooijer, A.,
.. \& Silvius, M. J. (2006). Interrelationships between hydrology and ecology in fire degraded tropical peat swamp forests. Water Resources Development, 22(1), 157-174.

22. Yusuf, A. A. (2006). Constructing Indonesian social accounting matrix for distributional analysis in the CGE modelling framework.

23. Yusuf, A. A. (2007). Constructing Indonesian Social Accounting Matrix for Distributional Analysis in the CGE Modelling Framework. MPRA Paper, 1730: 1-33.

24. Yusuf, A. A., \& Resosudarmo, B. P. (2015). On the distributional impact of a carbon tax in developing countries: the case of Indonesia. Environmental Economics and Policy Studies, 17(1), 131-156. 